\title{
Ethical Issues between Workforce and Religious Conviction
}

\author{
Mohamad Zaid Mohd Zin ${ }^{1}$, Ahmad Faisal Mahdi ${ }^{2}$, Azhar Abdul Rahman ${ }^{1}$, Mohd Syahiran Abdul Latif ${ }^{1}$, Rohaya \\ Sulaiman $^{1}$, Nurul Khairiah Khalid ${ }^{1}$, Nurfahiratul Azlina Ahmad ${ }^{1}$, Ahamad Asmadi Sakat ${ }^{3}$ Adi Yasran A A ${ }^{4}$ \& \\ Mohd Roslan Mohd Nor ${ }^{5}$ \\ ${ }^{1}$ Centre for Islamic Thought and Understanding, University Technology Mara, Samarahan, Malaysia \\ ${ }^{2}$ Faculty of Business Managment, University Technology Mara, Samarahan, Malaysia \\ ${ }^{3}$ Department of Al Quran and Al Sunnah Studies, Faculty of Islamic Studies, Universiti Kebangsaan Malaysia, \\ Selangor, Malaysia \\ ${ }^{4}$ Department of Malay Language, Faculty of Languages and Communication, Universiti Putra Malaysia, \\ Selangor, Malaysia \\ ${ }^{5}$ Department of Islamic History and Civilization, Academy of Islamic Studies, University of Malaya, Kuala \\ Lumpur, Malaysia
}

Correspondence: Mohamad Zaid Mohd Zin, Centre for Islamic Thought and Understanding, University Technology Mara, 94300 Samarahan, Sarawak, Malaysia. E-mail: zaiduitm@gmail.com

Received: May 18, 2012 Accepted: July 1, 2012 Online Published: August 17, 2012

doi:10.5539/ass.v8n11p50 URL: http://dx.doi.org/10.5539/ass.v8n11p50

\begin{abstract}
Problem statement: This article enhances the ethical issues consider the relationship between religious life and work ethics. Approach: Malaysia aim to achieved full developed nation's, requires a professional workforce, not only educated and innovative, but ethically, with integrity, accountability, dynamic and committed to continuously increasing Muslim professionalism. In the context of the development of Muslim professionals with a holistic and integrated, Muslims needs to withholding Tawheed, the fundamentals of faith, based on Al-Quran and Hadith. Manifestations in life of the practice which accounts for worship and morality need to be implemented. Results: Islamic moral character requires the emphasize that following five key parameters of Islamic behavior which is justice, trust, righteousness, the struggle towards self-improvement and keeping promises. Conclusion: The properties of trust at work, honesty, responsibility and integrity should be established in each of the Muslims. Each institution needs to be continued in the religious education and level of consciousness must be nurtured and enhanced.
\end{abstract}

Keywords: ethics, workforce, Muslim professionalism, religious, Tawheed

\section{Introduction}

Muslims, especially in Malaysia believe that Islam is not only a religious, but also a guide line for life itself. Muslims believe that Islam is a complete life code and at the core of Islamic moral character is faith in God. As Maudoodi (1991) points out, "Iman (faith) is the seed and Islam is the fruition." However, the increasing evidence of Muslims unethical behavior in the workplace now more disquiet, indicating that faith level has been impaired.

Hoffman et al. (2002) said, to establishing an ethical culture needed an equilibrium balance between institutional authority and individual autonomy, while providing proper guidance through codes, rules and policies. The critical task is to develop ethical behavior among employees and enhance their skills in ethical decision making. Workers who adhere to ethical lines typically have a high commitment to work within the organization, as well as potentially positive change and are considered beneficial and generate a profit, compared with workers who are less ethical.

\section{Materials and Methods}

The concept of ethics comes from the Greek word 'ethos'. Oxford dictionary defines ethics as a group of moral principles governing the behavior, which refers to the individual philosophy in the moral principles and values. 
In addition, ethics is considered as the law or regulations, a religious belief, individual conscience, generally accepted customs, practices that coincide with the interests of the individual or concerned with the philosophical theory about the rationality of moral behavior. (International Encyclopedia of Social Sciences, 1968)

Ethics is a highly elusive, enigmatic, complex and sensitive concept. It is a moral or ethical statement that may assert some particular action which is right or wrong; or that some actions of certain kinds are so; it may offer a distinction between good and bad characters or dispositions. (Yogesh Upadhyay et al, 2010) According to Lamb et al. 2004; Yogesh Upadhyay et al, 2010), ethics refers to the 'moral principles or values that generally govern the conduct of an individual or a group'. Fowler, (1994); Latifi, (1997) said ethics is concerned with the evaluation of choices where the options are not clear, or where there is no absolute right or wrong answer. This concept actually implies a reasoning capability that permits an individual to render judgment unaltered by self-interest that would impair the responsibilities to the public.

Ethics has a function in the management system and emphasized in Islam. Ethics management framework using a set of Islamic values that is formulated in a special code, as a guideline for each individual to decide whether the actions and moral behavior, acceptable to the organization, favored by the community and more importantly, it does not violate the requirements of legislation. In the Islamic perspective, attitude and work ethic mean emission derived from deeds of faith, including life style and the paradigm consisted with working system. Islam considers the concept of work ethics, dedication to work as a charity. It also stressed the attitude of cooperation, tolerance and consultation which was considered the best in the depths of the organization. In addition, employment deemed a way to increase self-reliance measure and meet the satisfaction level of every human being.

Ethics within Islamic Intellectual Discourse

Ethics may be defined as the set of moral principles that distinguish what is right from what is wrong. It is a normative field because it prescribes what one should do or abstain from doing. Within an Islamic context, the term most closely related to ethics in the Qur'an is khuluq. The Qur'an also uses a whole array of terms to describe the concept of goodness: khayr (goodness), birr (righteousness), qist (equity), 'adl (equilibrium and justice), haqq (truth and right), ma'ruf (known and approved), and taqwa (piety). Pious actions are described assalihat and impious actions are described as sayyi'at. (Fakhry Majid, 1991).

Siddiqui A. (1997) states, Islamic ethics as a cohesive discipline does not exist. Material on ethics is scattered throughout the Islamic sciences of Fiqh (jurisprudential understanding), Tafsir (Qur'anic exegenesis), and Kalam (scholastic theology). Islamic ethics incorporates various philosophical traditions it still holds a religious worldview and draws its resources mainly from religious texts.

Morals are the most accurate ethics term in Islam. It refers to the character and human nature. In Arabic, terms that approximate the meaning of ethics are Akhlaq and Adab. Akhlaq is derived from an Arabic root word meaning 'to create' or 'to form' thereby signifying innate qualities, and is used to mean morality or character. While in English, terms 'ethics' and 'morality' have different origins and connote different meanings, the former being what is 'appropriate and rational' and the latter being more subjective and amenable to change over time, being what is 'commonly felt and done'. (Padela, A. I., 2007)

The concept of Islamic work ethics has its origin in al - Qur'an, the sayings and the practices of Prophet Muhammad (pbuh). Al - Qur'an speaks about honesty and justice. In Islamic work ethics, there is no room for laziness and waste of time, either by remaining idle or engaging oneself in an unproductive activity. The Islam work ethics view dedication to work as a virtue. Sufficient effort should go into one's work, which is seen as obligatory for a capable individual.

The Islamic work ethics emphasizes cooperation in work, and consultant encouraged to overcome obstacles and avoid mistakes (Darwish, 2000). Hard work is seen as a virtue, and those who work hard are more likely to get ahead in life. Conversely, not working hard is seen to cause failure in life. The value of work in the Islamic work ethics is derived from both the accompanying intention and the results of the work, if all necessary requirements are fulfilled.

Whatever the definition given, spiritual development (ethics) in itself can be defined as constructive character, personality and behavior with the goal of a civilized, intellectual, moral and viable. People should strive and willing to change themselves, leading to greater transformation. Moreover, personality development efforts need commitment and patience. Thus, ethics important and give positive impact on families, communities and countries. Each practice or the work performed requires good faith, so that all the works taken to Mercy, simplified and pleasing to God. 


\section{Results and Discussion}

Ethical Issues in the Workforce and its Corrective Measures

Due to the increased high labor demand in all sectors, both government and the private sector are embarking on a system to sort employees. A variety courses, programs, education and training have been established, implemented and its aims to nurture talents, physical, and physical skills. However, many oblivious that man consists two elements of spiritual and physical and need a balanced demand for both. Majority only concerned about the development of a material with no emphasis on spiritual development.

Islam requires its followers to excel in both these aspects. In fact, aspects of personality must be a priority. This is because the physical development can be improved only after a spiritual aspect become excellent. Although the number of highly educated human capital is increasing, but still existing such undesirable deviation, corruption, embezzlement, fraud and non productive employee at workplace. Therefore, it is important that the continued strengthening of the Muslim generation, graduates need to be keep address with religious demands.

A recent review of articles published in the Wall Street Journal during only one week in 1991 uncovered a whole array of issues being faced by employees including stealing, lying, fraud and deceit. (Cherrington, 1993) There are multiple factors that affecting ethical behavior including stages of moral development, personal values and morals, family influences, peer influences, and life experiences.

The high cost of unethical behavior to companies can include heavy fines, embarrassment, the loss of public confidence and reputation, low employee morale, a disruption in the normal business routine and difficulty in recruiting. To prevent these difficulties, all people in work field need to have heightened awareness of the ethical implications of the decisions they face. According to Rest, 1986; Cherrington, 1993, the individual facing a decision with moral content first recognizes the moral issue, then makes a moral judgment, establishes moral intent, and, finally, engages in moral behavior.

Latifi (1997) found that the work related characteristics available in Muslim workforce are equality, responsibility, cooperation, kindness and consultation. He also claim that Muslim scholars identified several work related characteristics which fulfill requirements of modern management practices and provided a dual benefit for them. Firstly, having their roots in al - Qur'an and Sunnah, help eliminate ethical dilemma, which mainly occur due to the weakness of the individual's character.

Hasan (2002) explained in Pokok-pokok Materi Metodologi Penelitian dan Aplikasinya that the relationship with God would be inspired by the values of truthfulness, fairness, kindness, uprightness rather than envy, backbiting and discrimination. Besides that, the fundamental of Islam such as aqidah,( belief and faith) ibadah (worship) and akhlaq (morality and ethics) are not subject to change, their manifestation in secondary areas like economics, business and other worldly activities would require flexibility and development according to time and space (Kamali, 1989). This is embodied in Islamic Shariah which is central to the worldview of Islam. Normally, the Shariah as Islamic Law (Dusuki, 2008), but the boundaries of Shariah extend beyond the limited horizons of law.

The Canadian Medical Association (2001) provides guidelines to the professionalism for elements such as competencies, attitudes, and behavior, manifested by the workforce in the process of discharging their duties, based on the concept of continuous improvement skills, ethical behavior in the course of their duties with integrity, honesty, sincerity, fairness, respect, accountability and other precision element with a code of ethics specific areas.

Furthermore, it is important to increase students' business ethics facility to recognizing the variety of ethical issues in the workplace (Hartman, 2007; Williams \& Dewett, 2005; Susan D. Baker et al, 2012) and applying moral criteria as they consider. With this, students and prospective employees enable to identify a broad variety of ethical issues in the workplace, applied moral reasoning to these issues and enhance students' ability to make decisions that consider the relationship between organizational factors and ethical behavior.

While Steven Eric Krauss (2005) create a model and instrument for measuring religiosity from the Islamic perspective are attainable. The Muslim Religiosity and Personality Inventory (MRPI) based on a multi-dimensional and comprehensive religiosity concept reflective of key dimensions of the Islamic tawhidic worldview. The field test findings indicated that there are significant differences in youth religiosity normed scores across the six sub-populations of youth sampled. He also concluded that there are considerable differences in religiosity among different groupings of Muslim youth in Malaysia, which potentially reflects differences in key competencies integral for positively contributing to nation building.

Hence, Azimi Hamzah et.al (2007) claim that the religiosity instrument appropriate for Muslim are still lacking. The theoretical explications on religion and religiosity in Islam are numerous (Hassan and Khalique, 1981 ; 
Khairul Anwar Mastor, 2000). The proposes in the development of a religiosity instrument measuring religiosity adherence, attitudes and orientation is needed first, prior to a detailed study on the relationship between religiosity and personality behavioral correlates.

\section{Conclusion}

Islam was a comprehensive lifestyle and morality is an Islamic regulations embranchment. Personal values and individual personality will also influenced ethical standards. Through encouragement and a sense of obedience to God, people will comply with moral regulations, without any external pressure. While, ethics represents human's characteristic and individuality. Starting to situate a professional mindset and changed attitude to measure results creatively, and learning to cultivate and followed the best instincts (Kleiner 2002; Donaldson, Thomas 1994). The properties of trust at work, honesty, responsibility and integrity should be established. Each institution needs to be continued in the religious education. Level of consciousness must be nurtured and enhanced. If not, the society and the country will be lost, and worse, the quality of the Muslims themselves would be destroyed.

\section{References}

Azimi Hamzah, Steven Eric Krauss @ Abdul Lateef Abdullah, Sidek Mohd. Noah, Turiman Suandi, Rumaya Juhari, Jamiah Manap, Khairul Anwar Mastor, Azma Mahmoud, \& Hasnan Kassan. (2007). Muslim Religiosity and Personality Assessment : Prototype for Nation Building. Institute for Social Science Studies (IPSAS), Universiti Putra Malaysia.

$\begin{array}{llll}\text { Canadian } & \text { Medical } & \text { Association. } & \text { (2001). Retrieved from }\end{array}$ http://www.cna-aiic.ca/CNA/practice/ethics/code/resources/default_e.aspx

Cherrington, J. O., \& Cherrington, D. J. (1993). A Menu of Moral Issues: One Week in the Life of the Wall Street Journal. Journal of Business Ethics.

Darwish A. Y. (2000). Organizational Commitment as a Mediator of the Relationship between Islamic Work Ethics and Attitudes toward Organizational Change. Human Relationship, 53(4), 513-537. http://dx.doi.org/10.1177/0018726700534003

Darwish A. Y. (2000). The Islamic work ethic as a mediator of the relationship between locus of control, role conflict and role ambiguity: A study in an Islamic country setting. Journal of Managerial Psychology, 15, 283-302. http://dx.doi.org/10.1108/02683940010330966

Donaldson Thomas. (1994). Ethics in Business: A New Look. In T. A. Mathias (Ed.), Corporate Ethics. New Delhi: Allied Publishers Ltd.

Fakhry, Majid. (1991). Ethical Theories in Islam. Leiden: E. J. Brill.

Hoffman, W. Michael, Dawn-Marie Driscoll, \& Mollie Painter-Morland. (2002). Integrating Ethics into Organisational Cultures. In Chris Moon, \& Clive Bonny (Eds.), Business Ethics. London: The Economist Books.

Latifi F. (1997). Management learning in national context. Unpublished PhD thesis, Henley Management College.

Padela, A. I. (2007). Islamic Medical Ethics: A Premier Bioethics.

Sayyid Abu A'la Maudoodi. (1991). The Islamic Movement: Dynamics of Values, Power and Change, edited by Khurram Murad. Leicester, UK: The Islamic Foundation.

Siddiqui A. (1997). Ethics in Islam: key concepts and contemporary challenges. Journal Moral Education, 26(4), 423-431. http://dx.doi.org/10.1080/0305724970260403

Sills, David L., \& Merton, Robert King. (1968). International Encyclopedia of Social Sciences. The MacMillan Co. and The Free Press.

Steven Eric Krauss. (2005). Development of the Muslim Religiosity-Personality Inventory for Measuring the Religiosity of Malaysian. Universiti Putra Malaysia.

Susan D. Baker, \& Debra R. Comer. (2012). Business Ethics Everywhere: An Experiential Exercise to Develop Business Students' Ability to Identify and Respond to Ethical Issues. Journal of Management Education. http://dx.doi.org/10.1177/1052562911408071

Yogesh Upadhyay, \& Shiv Kumar Singh. (2010). In Favour of Ethics in Business: The Linkage between Ethical Behaviour and Performance. Journal of Human Values. 